\title{
CORROSION RESISTANCE AND BEHAVIOR OF CONSTRUCTION MATERIALS EXPOSED TO DILUTE SULFURIC ACID AT ELEVATED

\author{
TEMPERATURES UNDER STATIC CONDITIONS
}

\author{
D. T. Nguyen \\ Tennessee Valley Authority \\ P.O. Box 1010 \\ Muscle Shoals, AL 35660-1010
}

\begin{abstract}
Laboratory investigation has been undertaken to determine the electrochemical behavior and corrosion resistance of various construction materials in a simulated hydrolysis environment ( $5 \mathrm{wt} \%$ sulfuric acid) at temperatures ranging from 90 to $220^{\circ} \mathrm{C}$. Tests were performed in an autoclave-type electrochemical cell. The corrosion behavior of the test materials was determined using computer-controlled DC potentiodynamic polarization. Corrosion rates of the test materials were determined using AC impedance techniques. Among the stainless steels tested, only alloy N08026 (Carpenter 20Mo-6) performed satisfactory up to a temperature of $100^{\circ} \mathrm{C}$. The alloy passivated spontaneously in the environment and corroded at a rate of less than 2 mpy. None of the stainless steels tested could be used at $120^{\circ} \mathrm{C}$ or above. A number of nickel-based alloys tested had good corrosion resistance up to $100^{\circ} \mathrm{C}$, but their corrosion rate exceeded $2 \mathrm{mpy}$ at higher temperatuares. Zirconium alloys were satisfactory up to $180^{\circ} \mathrm{C}$. Only tantalum and a tantalum-niobium alloy were satisfactory up to $220^{\circ} \mathrm{C}$.
\end{abstract}




\section{DISCLAIMER}

This report was prepared as an account of work sponsored by an agency of the United States Government. Neither the United States Government nor any agency thereof, nor any of their employees, make any warranty, express or implied, or assumes any legal liability or responsibility for the accuracy, completeness, or usefulness of any information, apparatus, product, or process disclosed, or represents that its use would not infringe privately owned rights. Reference herein to any specific commercial product, process, or service by trade name, trademark, manufacturer, or otherwise does not necessarily constitute or imply its endorsement, recommendation, or favoring by the United States Government or any agency thereof. The views and opinions of authors expressed herein do not necessarily state or reflect those of the United States Government or any agency thereof. 


\section{DISCLAIMER}

Portions of this document may be illegible in electronic image products. Images are produced from the best available original document. 


\section{Introduction}

Corrosion of construction materials for the hydrolysis reactor (hydrolyzer) is a serious problem because of the acid environment and elevated temperatures required for the reactions. In small-scale studies, only highly corrosionresistant materials, such as zirconium alloys and tantalum, have been selected for the hydrolysis reactors and accessories. These refractory metals provide adequate corrosion performance in the hydrolysis environment, but their application is limited by their high cost and lack of availability. Currently, numerous high-chromiumnickel stainless steels and nickel-based alloys are available commercially at reasonable cost. However, existing data on corrosion resistance of these materials in the hydrolysis environment are inadequate, particularly at temperatures approaching and above the boiling point $\left(100^{\circ} \mathrm{C}\right)$.

The objective of this study is to determine corrosion behavior of various construction materials exposed to a simulated hydrolysis environment $(5 \mathrm{wt} \%$ dilute sulfuric acid at temperatures ranging from 90 to $220^{\circ} \mathrm{C}$ ) by studying electrochemical potential-current relationships using $\mathrm{DC}$ potential polarization scan techniques. The general corrosion of test materials in the simulated hydrolysis environment was determined using $\mathrm{AC}$ impedance techniques. Results of the study provide basic information needed for proper material selection for hydrolysis reactors and associated equipment. The results also suggest that appropriate corrosion protection should be provided, if lower corrosion resistance, lessexpensive materials are considered. Table 1 shows the compositions of the alloys, Unified Numbering System (UNS), trade name, and relative cost compared with stainless steel S31603 (TVA 1989). The passivity behavior of the alloys was studied using DC.potentiodynamic polarization techniques (Liening 1986; ASTM 1992). General corrosion rates were determined using AC Impedance Spectroscopy (ASTM 1992).

\section{Experiment}

The test cell consisted of a PARR reactor constructed of stainless steel S31603. The cell interior was lined with $1 / 8$-inch $(0.32-\mathrm{cm})$ thick Teflon. The internal volume of the cell was approximately 2 liters. The cell was equipped with three identical electrode holders made of stainless steel S31603 and lined with Teflon for chemical and electrical insulation. One holder was used for the working electrode (test specimen) and it was located in the center of the cell. Two other holders were used for the reference and counter electrodes. They were located at the same level, on opposite sides, and 1.2 inches $(3 \mathrm{~cm})$ from the working electrode. All electrodes were electrically isolated from the test cell using alumina ceramics.

Test electrodes were designed and fabricated to conform with ASTM Standard G 3-89 (ASTM, 1992) and consisted of a 3/8-inch $(0.95-\mathrm{cm})$ diameter and 0.5 -inch $(1.2-\mathrm{cm})$ high cylindrical specimen with a total exposed area of approximately $0.82 \mathrm{in}^{2}\left(5.3 \mathrm{~cm}^{2}\right)$. The surface of the electrodes was machined to a 600 -grit finish. The counter and reference electrodes were made of platinum. The tests (DC potentiodynamic and AC impedance) were conducted in accordance with ASTM Standard G 3-89. A 1-liter volume of fresh test solution was used for each test. The test solution was made using $98 \mathrm{wt} \%$ reagent sulfuric acid and distilled water to obtain a concentration of $5 \mathrm{wt} \%$. The test specimen, counter, and reference electrodes were ultrasonically cleaned in actone, installed into the electrode holders, and then immersed in the test solution. The entire test cell was heated at an average rate of $1.5^{\circ} \mathrm{C} /$ minute using an electric furnace. The thermocouple was located at approximately the same level in the test cell as the test electrodes to ensure that the test temperature was uniform between these electrodes. The test temperature was controlled digitally within $\pm 3^{\circ} \mathrm{C}$ from the temperature setpoint. After the test temperature was reached, 
Table 1. Major Alloy Compositions of Contruction Materials Exposed to 5 wt\% Sulfuric Acid at Elevated Temperatures and Static Conditions

\begin{tabular}{|c|c|c|c|c|c|c|c|c|c|c|c|c|c|}
\hline \multirow{2}{*}{$\begin{array}{r}\text { Mat } 1 \\
\text { tested }\end{array}$} & \multirow{2}{*}{$\begin{array}{r}\text { Trade } \\
\text { Name }\end{array}$} & \multicolumn{11}{|c|}{ Composition, wto } & \multirow{2}{*}{$\begin{array}{l}\text { Cost } \\
\text { rat } 10 a \\
\end{array}$} \\
\hline & & & $C F$ & $\mathrm{Ee}$ & & $\mathrm{Mn}$ & $\mathrm{MO}$ & No & & $\underline{S 1}$ & $\mathrm{Ta}$ & other & \\
\hline $\begin{array}{l}\text { S31603 } \\
\text { N08904 } \\
\text { N08020 } \\
\text { N08026 }\end{array}$ & $\begin{array}{l}\text { Type } 316 \mathrm{~L} \\
\text { Type } 904 \mathrm{~L} \\
\text { Carp 20Cb-3 } \\
\text { Carp 20MO-6 }\end{array}$ & $\begin{array}{l}0.03 \\
0.02 \\
0.07 \\
0.03\end{array}$ & $\begin{array}{l}18 \\
23 \\
21 \\
26\end{array}$ & $\begin{array}{l}\mathrm{Bal} \text {. } \\
\mathrm{Bal} \text {. } \\
\mathrm{Bal} \text {. } \\
\mathrm{Bal} \text {. }\end{array}$ & $\begin{array}{l}2.0 \\
2.0 \\
2.0 \\
1.0\end{array}$ & $\begin{array}{l}3.0 \\
5.0 \\
3.0 \\
6.0\end{array}$ & $\stackrel{-}{1.0}$ & $\begin{array}{l}12 \\
28 \\
38 \\
37\end{array}$ & $\begin{array}{l}1.0 \\
1.0 \\
1.0 \\
0.5\end{array}$ & $\begin{array}{l}- \\
- \\
-\end{array}$ & $\begin{array}{l}- \\
- \\
-\end{array}$ & $\begin{array}{l}2 . \overline{O C u} \\
4.0 \mathrm{Cu} \\
4.0 \mathrm{Cu}\end{array}$ & $\begin{array}{l}1.0 \\
1.4 \\
2.2 \\
2.3\end{array}$ \\
\hline $\begin{array}{l}\text { N02200 } \\
\text { N04400 } \\
\text { N10665 } \\
\text { N08825 } \\
\text { N0 } 6030 \\
\text { N08625 }\end{array}$ & $\begin{array}{l}\text { Nickel } 200 \\
\text { Monel } 400 \\
\text { Hast. B-2 } \\
\text { Incoloy } 825 \\
\text { Hast. G-30 } \\
\text { Inconel } 625\end{array}$ & $\begin{array}{l}- \\
- \\
0.01 \\
0.05 \\
0.03 \\
0.10\end{array}$ & $\begin{array}{l}- \\
\overline{1} \cdot 0 \\
2 \overline{2} \\
30 \\
22\end{array}$ & $\begin{array}{r}- \\
- \\
2 \\
29 \\
15 \\
5\end{array}$ & $\begin{array}{l}- \\
- \\
- \\
-\end{array}$ & $\begin{array}{l}- \\
28 \\
3.0 \\
5.5 \\
9.0\end{array}$ & $\begin{array}{l}- \\
- \\
- \\
0.8 \\
4.0\end{array}$ & $\begin{array}{r}100 \\
70 \\
\mathrm{Ba1} \\
42 \\
43 \\
62\end{array}$ & $\begin{array}{l}- \\
- \\
0.1 \\
0.5 \\
1.0 \\
0.5\end{array}$ & $\begin{array}{l}- \\
- \\
- \\
-\end{array}$ & $\begin{array}{l}- \\
\overline{-} \\
\overline{-} \\
\text { - }\end{array}$ & $\begin{array}{c}- \\
30 \mathrm{Cu} \\
- \\
2 \mathrm{Cu}, 1 \mathrm{~T} 1 \\
2.5 \bar{w} \\
-\end{array}$ & $\begin{array}{l}1.5 \\
2.0 \\
7.0 \\
2.3 \\
5.0 \\
2.3\end{array}$ \\
\hline $\begin{array}{l}\text { N06022 } \\
\text { N10276 } \\
\text { R06702 } \\
\text { R06705 } \\
- \\
-\end{array}$ & $\begin{array}{l}\text { Hast. C-22 } \\
\text { Hast. C-276 } \\
\mathrm{Zr} 705 \\
\mathrm{Zr} 702 \\
\mathrm{KBI}-40 \\
\text { Tantalum }\end{array}$ & $\begin{array}{l}0.01 \\
0.01 \\
0.05 \\
0.05 \\
- \\
-\end{array}$ & $\begin{array}{l}22 \\
16 \\
<.2 \\
<.2 \\
- \\
-\end{array}$ & $\begin{array}{l}- \\
5.5 \\
<.2 \\
<.2 \\
- \\
-\end{array}$ & $\begin{array}{l}- \\
- \\
3.0 \\
-\end{array}$ & $\begin{array}{r}10 \\
16 \\
- \\
- \\
-\end{array}$ & $\begin{array}{c}2.0 \\
- \\
40^{-}\end{array}$ & $\begin{array}{r}53 \\
57 \\
- \\
- \\
- \\
-\end{array}$ & $\begin{array}{l}0.08 \\
- \\
- \\
-\end{array}$ & $\begin{array}{l}- \\
- \\
\overline{-} \\
60 \\
\text { Bal. }\end{array}$ & $\begin{array}{l}\overline{-} \\
95 \\
91 \\
- \\
-\end{array}$ & $\begin{array}{l}3.0 \mathrm{~W} \\
4.0 \mathrm{~W} \\
4.5 \mathrm{HE} \\
4.5 \mathrm{Hf} \\
0.3 \mathrm{~W} \\
-\infty\end{array}$ & $\begin{array}{r}6.0 \\
6.0 \\
4.6 \\
4.6 \\
50.0 \\
120.0\end{array}$ \\
\hline
\end{tabular}

a Relative cost ratio versus stainless steel s31603, Material F1les, Muscle Shoals Corrosion Laboratory, National Fertilizer \& Environmental Research Center, Alabama.

the test specimen was allowed to stabilize in the test solution for at least 30 minutes. The $\mathrm{AC}$ impedance test was then conducted for approximately 3 minutes. Next, the potentiodynamic polarization test was performed on the same specimen.

The AC impedance test was conducted using an EG\&G Princeton Applied Research Model 378 electrochemical system and Model 388 AC impedance software. The polarization resistance, $R_{p}$, which is inversely proportional to the corrosion rate, was determined from the diameter of the Nyquist semicircle. The corrosion current density of the test specimen was calculated from the value of $R_{p}$ by the following equations (Liening 1986; ASTM 1992):

$$
I_{\text {cort }}\left(\mu \mathrm{A} / \mathrm{cm}^{3}\right)=\times 10^{6} \times B_{2} \times B_{c} /\left[2.3 \times\left(B_{2}+B_{c}\right) \times R_{p} \times A\right]
$$

Where $I_{\text {corr }}$ is corrosion current. density, $B_{a}$ and $B_{c}$ are Tafel slopes, $R_{p}$ is polarization resistance, and $A$ is the exposure area of the specimen. Approximate values for Tafel slopes were selected to be equal to $100 \mathrm{mV}$ for all test materials. The corrosion rate then can be calculated from the value of $R_{p}$ using the following relationship (ASTM 1992):

$$
\text { Rate }(\mathrm{mpy})=2826 \times \mathrm{xW}\left(\mathrm{dxAxR}_{\mathrm{p}}\right)
$$

Where mpy is mils per year, EW is equivalent weight, and $\mathrm{d}$ is alloy density. After $\mathrm{AC}$ impedance tests, anodic polarization tests were performed by scanning the surface potential of the test specimen from about $-250 \mathrm{mV}$ to 1600 $\mathrm{mV}$ versus the corrosion potential $\left(\mathrm{E}_{\text {corr }}\right)$, or to a current density of $10^{4} \mu \mathrm{A} / \mathrm{cm}^{2}$, at a scan rate of $0.7 \mathrm{mV} / \mathrm{s}(0.6 \mathrm{~V} / \mathrm{hour})$. The test was conducted using an EG\&G Princeton Applied Research Model 273 potentiostat and Model M342C electrochemical software in conjunction with a personal computer. Test data are presented in the form of specimen surface potential $E(\mathrm{mV})$ versus specimen current density $\left(\mathrm{A} / \mathrm{cm}^{2}\right)$ in semi$\log$ scale. Passivity and corrosion behavior of the test materials were determined using the values of the corrosion potential $\left(\mathrm{E}_{\text {corr }}\right)$, the primary passivation potention $\left(\mathrm{E}_{\mathrm{pp}}\right)$, the breakdown potential $\left(\mathrm{E}_{\mathrm{b}}\right)$, the critical passivation current density $\left(I_{c}\right)$, the passive current density $\left(\mathrm{L}_{\mathrm{p}}\right)$, and the shape of the anodic polarizations curve.

\section{Results and Discussion}

For handling chemical media in which corrosion attack is uniform, metals are classified into four groups according to the uniform corrosion rate and intended application (ASM 1985; Fontana et al. 1970). 
Excellent corrosion resistance: Metals corrode at rates of $2 \mathrm{mpy}$ or less. These metals are normally specified for very critical components such as reactors. These metals are also selected for the conditions in which contamination of heavy metal ions may impair process reaction or lead to serious health hazards.

Good corrosion resistance: Metals corrode at rates of 2 to $5 \mathrm{mpy}$ and are selected for critical components such as valves and pump shafts.

Fair corrosion resistance: Metals and alloys corrode at rates of 5 to 50 mpy. These metals are frequently selected for parts tolerable to some corrosion such as storage tanks, piping, pumps, and valve housings. Corrosion allowance is required to supplement for the loss of metal due to corrosion.

Severe corrosion of the hydrolysis reactor materials is not acceptable, because of the conditions of high temperature and pressure. In addition, high corrosion may cause serious contaminaton to the hydrolysis environment as well as to the downstream processes. Therefore, selection of materials for the hydrolysis reactors should be limited to metals with excellent corrosion rates of 2 mpy or less. For passive metals, the passivation should be stable (low critical and passive current densities) and spontaneous (metal corrodes in the passive range; the corrosion potential must be more noble than the $\mathrm{E}_{\mathrm{pp}}$ ). The passive current density should be equivalent to a corrosion rate not exceeding 2 mpy.

The AC and DC test results are listed in Tables 2 and 3. Figures 1 to 4 show examples of the DC potentiodynamic polarization of the test materials. Figure 5 shows the $\mathrm{AC}$ impedance data for the test materials.

\section{Stainless Steels}

At 90 and $100^{\circ} \mathrm{C}$, results of the $\mathrm{AC}$ impedance tests showed that alloys S311603, N08904, and N08020 have poor-to-fair corrosion resistance (corrosion rate greater than 5 mpy, Table 2).
The potentiodynamic polarization scan tests revealed that all of these stainless steels exhibited stable passivation in $5 \mathrm{wt} \%$ sulfuric acid solution over a wide potential range (approximately $900 \mathrm{mV}$ ) and at low passive current densities $3 \mu \mathrm{A} / \mathrm{cm}^{2}$ or less). However, their passivation was not spontaneous. Therefore, these stainless steels were not satisfactory for hydrolysis service at either 90 or $100^{\circ} \mathrm{C}$.

Because the passive current density of these stainless steels was about $3 \mu \mathrm{A} / \mathrm{cm}^{2}$ or less, an average corrosion rate of less than $2 \mathrm{mpy}$ is achieved if these metals remain in the passive range. Examination of the DC potentiodynamic scan diagram revealed that these alloys corroded in the active range. The most stable corrosion potential recorded after the stabilization was more active than the primary passive potential (Table 2). In addition, several corrosion potentials were indicated by the shape of the polarization curves (Fig 1). This indicated that these stainless steels would corrode preferentially in the active or active-passive range. Passive corrosion is obtained on these stainless steels only when their corrosion potential potentiostatically polarized into the passive range. The initial current density required for complete polarization must exceed the alloy $i_{c}$ (400-800 $\mu \mathrm{A} / \mathrm{m}^{2}$ for alloy S31603, 210-250 $\mu \mathrm{A} / \mathrm{cm}^{2}$ for alloy N08904, and about 300 $\mu \mathrm{A} / \mathrm{cm}^{2}$ for alloy N08020), but the current density required to maintain passivation is equal to $i_{p}$ (between 2.5 and $3 \mu \mathrm{A} / \mathrm{cm}^{2}$ for all three alloys). This technique is known as anodic protection.

Because of its higher molybdenum content, alloy N08026 showed superior corrosion resistance compared to alloys S31603, N08904, and N08020. At 90 and $100^{\circ} \mathrm{C}$, the resistance to general corrosion of alloy N08026 was excellent. The alloy corroded at very low rates, 0.1 mpy at $90^{\circ} \mathrm{C}$ and $1 \mathrm{mpy}$ at $100^{\circ} \mathrm{C}$. The alloy exhibited spontaneous passivation, because the corrosion potential was more noble than the primary passive potential. The passive corrosion density 
Table 2. Results of Electrochemical Tests on Various Materials Exposed to 5 wt \% Sulfuric Acid at 90,100, and 1200C Under Static Conditions

\begin{tabular}{|c|c|c|c|c|c|c|c|c|}
\hline $\begin{array}{r}\text { Matls } \\
\text { tested }\end{array}$ & ohms & $\begin{array}{c}i_{\text {cor }} \\
\mu \mathrm{A} / \mathrm{cm}^{2}\end{array}$ & $\begin{array}{c}\text { Cor.Rate } \\
\text { mpy }\end{array}$ & $\begin{array}{l}E_{\text {cor }} \\
\mathrm{mV} / \mathrm{Pt}\end{array}$ & $\begin{array}{l}i_{c} \\
\mu A / \mathrm{cm}^{2}\end{array}$ & $\stackrel{i p}{i{ }^{2} \mathrm{~cm}^{2}}$ & $\begin{array}{l}E_{\mathrm{mp}} \\
\mathrm{mV} / \mathrm{P}_{\mathrm{t}}\end{array}$ & $\begin{array}{c}E_{\mathrm{b}} \\
\mathrm{mV} / \mathrm{Pt}\end{array}$ \\
\hline \multicolumn{9}{|l|}{ At $900 \mathrm{C}$} \\
\hline 531603 & 19 & 204 & 79 & -864 & 800 & 2.5 & -750 & 90 \\
\hline N08904 & 39 & 25.4 & 10 & -812 & 250 & 2.5 & -710 & 190 \\
\hline N08020 & 126 & 30.8 & 12.0 & -790 & 300 & 3.0 & -710 & 290 \\
\hline N08026 & 3,500 & 1.1 & 0.4 & -610 & 150 & 1.5 & -660 & 290 \\
\hline NO2 200 & 139 & 22.9 & 12.0 & -808 & $-{ }^{b}$ & $-b$ & $-b$ & $-b$ \\
\hline N04400 & 998 & 3.9 & 2.0 & -761 & $-^{\mathrm{b}}$ & $-b$ & $-{ }^{\mathrm{b}}$ & $-b$ \\
\hline N10665 & 2,000 & 2.0 & 1.0 & -679 & $-\mathrm{b}$ & $-b$ & $-b$ & $-b$ \\
\hline N08825 & 7,600 & 0.5 & 0.2 & -571 & $-e$ & 2.5 & $-e$ & 290 \\
\hline no6030 & 41,000 & 0.1 & $<0.0$ & -521 & $-e$ & 1.5 & $-e$ & 290 \\
\hline N08625 & 6,900 & 0.6 & 0.2 & -566 & $-c$ & 3.0 & -0 & 290 \\
\hline No 6022 & 17,500 & 0.2 & $0 . \overline{1}$ & -542 & $-e$ & 2.0 & $-e$ & 190 \\
\hline N10276 & 12,000 & 0.3 & 0.1 & -617 & $-c$ & 1.0 & $-\infty$ & 240 \\
\hline R60705 & 23,000 & 0.2 & $0 . \overline{2}$ & -637 & $-c$ & 1.0 & $-^{c}$ & $-c$ \\
\hline R60702 & 78,000 & 0.1 & $<0.1$ & -597 & $-c$ & 1.0 & $-e$ & $-c$ \\
\hline $\mathrm{KBI}-40$ & 41,000 & 0.1 & 0.1 & -663 & $-c$ & 1.0 & $-c$ & $-c$ \\
\hline $\mathrm{Ta}$ & 100,000 & $0.0^{a}$ & $<0.1$ & -658 & $-c$ & 1.0 & -8 & $-c$ \\
\hline \multicolumn{9}{|l|}{ At $1000 \mathrm{C}$} \\
\hline 5031603 & 15 & 258.8 & 100.0 & -790 & 400 & 2.5 & -712 & 263 \\
\hline N08904 & 100 & 38.8 & 15.0 & -713 & 210 & 3.0 & -678 & 163 \\
\hline No8 8020 & 80 & 48.5 & 19.0 & -726 & 300 & 2.0 & -637 & 263 \\
\hline N08026 & 2,300 & 1.7 & 1.0 & -626 & 10 & 2.0 & -637 & 363 \\
\hline NO2200 & 19 & 204.3 & 88.0 & -769 & $-b$ & $-b$ & $-b$ & $-b$ \\
\hline NO 4400 & 480 & 8.1 & 4.0 & -703 & $-b$ & $-b$ & -b & $-b$ \\
\hline N10665 & 900 & 4.3 & 2.0 & -706 & $-b$ & $-b$ & $-b$ & $-b$ \\
\hline N0 8825 & 5,000 & 0.8 & 0.3 & -526 & 170 & 3.0 & -612 & 363 \\
\hline No 6030 & 27,000 & 0.1 & 0.1 & -535 & -0 & 1.0 & $-c$ & 363 \\
\hline NO 8625 & 6,000 & $0 . \overline{6}$ & $0 . \overline{3}$ & -539 & 10 & 2.5 & -637 & 313 \\
\hline No 6022 & 18,000 & 0.2 & 0.1 & -509 & $-c$ & 2.0 & $-c$ & 363 \\
\hline N10276 & 6,400 & $0: 6$ & 0.3 & -512 & $-c$ & 1.5 & $-^{e}$ & 363 \\
\hline R60705 & 25,000 & 0.2 & 0.1 & -734 & $-c$ & 1.0 & $-c$ & $-c$ \\
\hline$R 60702$ & 33,000 & 0.1 & 0.1 & -662 & $-^{e}$ & 1.5 & $-c$ & $-c$ \\
\hline$K B I-40$ & 51,000 & 0.1 & 0.1 & -590 & $-e$ & 1.0 & $-c$ & -6 \\
\hline $\mathrm{Ta}$ & 63,000 & $0.0^{a}$ & $<0.0$ & -691 & $-=$ & 1.0 & $-\epsilon$ & $-e$ \\
\hline \multicolumn{9}{|l|}{ At $1200 \mathrm{C}$} \\
\hline 531603 & 2 & 2,588 & 1002.0 & -289 & 4000 & 10.0 & -250 & 300 \\
\hline N08904 & 60 & 64.7 & 26.0 & -337 & 300 & 15.0 & -325 & 400 \\
\hline N08020 & 30 & 129.4 & 51.0 & -388 & 800 & 15.0 & -375 & 450 \\
\hline N08026 & 160 & 24.3 & 10.0 & -389 & 900 & 10.0 & -450 & 300 \\
\hline No22200 & 10 & 338.2 & 166.0 & -410 & $-b$ & $-b$ & $-b$ & $-b$ \\
\hline NO 4400 & 105 & 37.0 & 16.0 & -265 & $-b$ & $-b$ & $-b$ & $-b$ \\
\hline N10665 & 120 & 32.4 & 15.0 & -473 & $-b$ & $-b$ & $-b$ & $-b$ \\
\hline NO 8825 & 163 & 23.8 & 9.0 & -309 & 100 & 10.0 & -275 & 600 \\
\hline NO 6030 & 180 & 21.6 & 8.0 & -329 & 105 & 9.0 & -375 & 500 \\
\hline N08625 & 135 & 28.8 & 11.0 & -250 & 200 & 10.0 & -200 & 600 \\
\hline N0 6022 & 212 & 18.3 & 7.0 & -289 & 2000 & 20.0 & -500 & 550 \\
\hline $\mathrm{N} 10276$ & 270 & 14.4 & 6.0 & -285 & 500 & 8.0 & -350 & 400 \\
\hline R60705 & 9,000 & 0.4 & 0.4 & -343 & $-^{c}$ & 2.5 & $-c$ & $-c$ \\
\hline$R 60702$ & 11,500 & 0.3 & 0.3 & -522 & $-c$ & 2.5 & $-c$ & $-c$ \\
\hline$K B I-40$ & 22,500 & 0.2 & 0.1 & -487 & $-c$ & 2.0 & $-c$ & $-c$ \\
\hline $\mathrm{Ta}$ & 22,000 & 0.2 & 0.1 & -545 & $-c$ & 1.5 & $-c$ & $-c$ \\
\hline
\end{tabular}

\footnotetext{
Less than $0.1^{\text {b }}$ No passivation observed. "Outside measured range of potential. d Can not determine.
} 
Table 3. Results of Electrochemical Tests on Various Materials Exposed to 5 wt \% Sulfuric Acid at 140 to $220 \circ \mathrm{C}$ Under Static Conditions

\begin{tabular}{|c|c|c|c|c|c|c|c|c|}
\hline $\begin{array}{r}\text { Matis } \\
\text { tested }\end{array}$ & $\begin{array}{c}R_{\mathrm{p}} \\
\text { ohms }\end{array}$ & $\mu \begin{array}{l}i_{\mathrm{cor}^{2}} \\
\mu \mathrm{A} / \mathrm{cm}^{2}\end{array}$ & $\begin{array}{c}\text { Cor.Rate } \\
\text { mpy }\end{array}$ & $\begin{array}{l}\mathrm{E}_{\mathrm{cor}} \\
\mathrm{mV} / \mathrm{Pt}\end{array}$ & $\mu \mathrm{i} c / \mathrm{cm}^{2}$ & $\underline{i_{P}}$ & $\begin{array}{c}E_{p Q} \\
\mathrm{mV} / \mathrm{Pt}\end{array}$ & $\begin{array}{c}E_{b} \\
m V / P t\end{array}$ \\
\hline \multicolumn{9}{|l|}{ At $1400 \mathrm{C}$} \\
\hline $\begin{array}{l}\text { N08904 } \\
\text { N08020 }\end{array}$ & $\begin{array}{l}0.23 \\
0.30\end{array}$ & $\begin{array}{l}16,578 \\
12,940\end{array}$ & $\begin{array}{l}6,646 \\
5,121\end{array}$ & $\begin{array}{l}-383 \\
-329\end{array}$ & 2000 & $\begin{array}{r}100 \\
1000\end{array}$ & $\begin{array}{r}-400 \\
-{ }^{d}\end{array}$ & $\begin{array}{l}400 \\
600\end{array}$ \\
\hline N08026 & 6 & 669 & 261 & -344 & 800 & 20 & -450 & 250 \\
\hline N4400 & 3 & 1553 & 674 & -266 & $-b$ & $-b$ & & $-b$ \\
\hline N10665 & 6 & 645 & 299 & -267 & $-b$ & $-b$ & $-b$ & $-b$ \\
\hline N08825 & 5 & 746 & 296 & -318 & 400 & 100 & -100 & 300 \\
\hline N0 6030 & 16 & 243 & 91 & -398 & 1000 & 50 & -350 & 100 \\
\hline N08625 & 26 & 149 & 59 & -306 & 100 & 50 & & 400 \\
\hline NO 6022 & 12 & 323 & 129 & -378 & 1000 & 100 & -275 & 600 \\
\hline N10276 & 11 & 353 & 147 & -336 & 2000 & 300 & -250 & 400 \\
\hline$R 60705$ & 12,000 & 0.4 & 0.4 & -325 & $-c$ & 3.5 & $-c$ & $-c$ \\
\hline R60702 & 16,000 & 0.3 & 0.2 & -548 & $-c$ & 2.5 & $-^{e}$ & $-^{e}$ \\
\hline$K B I-40$ & 25,000 & 0.2 & 0.1 & -229 & $-c$ & 2.0 & $-^{c}$ & $--^{c}$ \\
\hline $\mathrm{Ta}$ & 27,000 & 0.2 & 0.1 & -542 & $-c$ & 2.0 & $-0^{\circ}$ & $-^{c}$ \\
\hline \multicolumn{9}{|l|}{ At $160^{\circ} \mathrm{C}$} \\
\hline R60705 & 3,300 & 1.2 & 1.0 & -728 & $-c$ & 3.0 & $-c$ & $-c$ \\
\hline $\mathrm{R} 60702$ & 10,000 & 0.4 & 0.4 & -872 & $-c$ & 2.0 & $-c$ & $-=$ \\
\hline $\mathrm{KBI}-40$ & 6,000 & 0.6 & 0.5 & -589 & $-c$ & 1.5 & $-c$ & $-c$ \\
\hline Ta & 42,000 & 0.1 & 0.1 & -450 & $-c$ & 1.0 & $=$ & $-c$ \\
\hline \multicolumn{9}{|l|}{ At $170^{\circ} \mathrm{C}$} \\
\hline R60705 & 1,540 & 2.5 & 2.0 & -612 & $-e$ & 3.0 & $-c$ & $-c$ \\
\hline R60702 & 5,200 & 0.8 & 0.7 & -504 & $-c$ & 2.0 & $-c$ & $-c$ \\
\hline $\mathrm{KBI}-40$ & 4,300 & 0.9 & 0.6 & -578 & $-c$ & 2.0 & $-^{e}$ & $-c$ \\
\hline $\mathrm{Ta}$ & 30,000 & 0.1 & 0.1 & -677 & $-^{\circ}$ & 1.0 & $-\varepsilon$ & $-c$ \\
\hline \multicolumn{9}{|l|}{ At $180^{\circ} \mathrm{C}$} \\
\hline $\mathrm{R} 60705$ & 850 & 4.6 & 4.0 & -805 & $-c$ & 5.0 & $-c$ & $-c$ \\
\hline R60702 & 1,800 & 2.2 & 2.0 & -781 & $-c$ & 3.0 & $-a$ & $-^{c}$ \\
\hline $\mathrm{KBI}-40$ & 4,500 & 0.9 & 0.6 & -765 & $-c$ & 2.0 & $-c$ & $-\varepsilon$ \\
\hline $\mathrm{Ta}$ & 22,000 & 0.2 & 0.1 & -641 & $-c$ & 1.0 & $-\varepsilon$ & $-\varepsilon$ \\
\hline \multicolumn{9}{|l|}{ At $190^{\circ} \mathrm{C}$} \\
\hline R60705 & 810 & 4.8 & 5.0 & -726 & $-c$ & 15.0 & $-c$ & $-c$ \\
\hline R60702 & 1170 & 3.3 & 3.0 & -570 & $-e$ & 5.0 & $-e$ & $-e$ \\
\hline$K B I-40$ & 8500 & 0.7 & 0.3 & -631 & $-c$ & 3.0 & $-^{e}$ & $-e$ \\
\hline $\mathrm{Ta}$ & 46000 & 0.1 & 0.1 & -542 & $-\varepsilon$ & 1.0 & $-^{\circ}$ & $-^{e}$ \\
\hline \multicolumn{9}{|l|}{ At $200^{\circ} \mathrm{C}$} \\
\hline R60705 & 750 & 5.2 & 7.0 & -359 & $-e$ & 30.0 & $-c$ & 1,400 \\
\hline R60702 & 1,009 & 3.8 & 4.0 & -345 & $-{ }^{c}$ & 8.0 & $-c$ & 1,400 \\
\hline $\mathrm{KBI}-40$ & 2,100 & 1.9 & 1.0 & -279 & $-c$ & 5.0 & $-e$ & $-c$ \\
\hline $\mathrm{Ta}$ & 35,000 & 0.1 & 0.1 & -432 & $-^{\circ}$ & 2.0 & $-c$ & $-c$ \\
\hline \multicolumn{9}{|l|}{ At $210^{\circ} \mathrm{C}$} \\
\hline $\mathrm{R} 60705$ & 680 & 13.9 & 13.0 & -376 & $-c$ & 10.0 & $-c$ & 1.400 \\
\hline R60702 & 1,000 & 5.7 & 6.0 & -368 & $-c$ & 8.0 & $-c$ & 1,600 \\
\hline $\mathrm{KBI}-40$ & 1,000 & 3.9 & 3.0 & -368 & $-c$ & 8.0 & $-c$ & 1,600 \\
\hline & 7,500 & 0.5 & 0.4 & -587 & $-c$ & 3.0 & $-\varepsilon$ & 1.700 \\
\hline \multicolumn{9}{|l|}{ At $220^{\circ} \mathrm{C}$} \\
\hline $\begin{array}{l}R 6005 \\
R 600 ?\end{array}$ & 190 & 20.4 & 20.0 & -402 & $-c$ & 00.0 & $-c$ & 1,400 \\
\hline $\begin{array}{l}R 6002 \\
K B I-40\end{array}$ & 1,600 & $\begin{array}{l}6.5 \\
2.4\end{array}$ & $\begin{array}{l}7.0 \\
2.0\end{array}$ & $\begin{array}{l}-343 \\
-291\end{array}$ & $\begin{array}{l}-c \\
-c\end{array}$ & $\begin{array}{l}10.0 \\
10.0\end{array}$ & $\begin{array}{l}-c \\
-c\end{array}$ & $\begin{array}{l}1,250 \\
1,600\end{array}$ \\
\hline $\mathrm{Ta}$ & 3,300 & 1.2 & 1.0 & -247 & $-e$ & 3.0 & - & 1,00 \\
\hline
\end{tabular}

Less than 0.1 b: No passivation observed. " : Outside measured range of potential. a can not determine. 
was 1 to $1.5 \mu \mathrm{A} / \mathrm{cm}^{2}$. Thus, no corrosion protection is needed for $\mathrm{N} 08026$ at temperatures near the boiling point. At $120^{\circ} \mathrm{C}$, all four stainless steels corroded excessively. Corrosion rates of alloys S31603, N08904, and N08020 were 1000,26 , and 51 mpy, respectively, while alloy N08026 corroded at a rate of $10 \mathrm{mpy}$. Thus, alloys of this class are not satisfactory for hydrolysis service at $120^{\circ} \mathrm{C}$. Although passivation was observed on these test alloys, the passive and critical current densities were high and the passivation range was narrow. Thus, anodic protection would be difficuit and uneconomical under these conditions.

\section{Nickel and Ni-Cu Alloy}

Without addition of alloying elements, nickel N02200 (Nickel 200) only showed fair corrosion resistance (corrosion rate of $12 \mathrm{mpy}$ ) at $90^{\circ} \mathrm{C}$ and poor corrosion resistance (corrosion rate exceeding $200 \mathrm{mpy}$ ) at 100 and $120^{\circ} \mathrm{C}$. Thus, metal N02200 is unsatisfactory for hydrolysis service at temperatures near or above $90^{\circ} \mathrm{C}$.

Because of the high copper content, corrosion performance of alloy N04400 (Monel 400, 30\% $\mathrm{Cu}-70 \% \mathrm{Ni}$ ) is better than commercial nickel in $5 \mathrm{wt} \%$ sulfuric acid. The alloy showed excellent resistance (corroded at rate of less than $2 \mathrm{mpy}$ at $90^{\circ} \mathrm{C}$ ). However, corrosion of alloy N04400 increased as temperature increased. Corrosion resistance of alloy $\mathrm{N} 04400$ shifted from excellent (2 mpy) at $90^{\circ} \mathrm{C}$, to good (4 mpy) at $100^{\circ} \mathrm{C}$, to fair $(16 \mathrm{mpy})$ at $120^{\circ} \mathrm{C}$, and to poor $(674 \mathrm{mpy})$ at $140^{\circ} \mathrm{C}$.

Potentiodynamic polarization test results indicate that neither alloy N02200 nor alloy N04400 showed passivity. Both anodic and cathodic polarizations of alloy N02200 and alloy N04400 exhibited classic Tafel behavior (Fig 1). At all test temperatures, an almost vertical-slope segment was observed on the cathodic polarization curves of alloy N04400, but no similar segment was seen on alloy N02200 (Fig 1 and 2). This behavior indicates that diffusion of cathodic species is a rate-controlling step in the corrosion of alloy N04400, but not in N02200. Transport of reactant species through the thick film of corrosion products was attributed to diffusion. The increase in corrosion of alloys N02200 any N04400 corrosion with temperature was also evidenced by shifting of the alloy polarization curves in the direction of increased current density as the test temperatures was increased.

\section{Ni-Mo Alloy}

Only alloy N10665 (Hastelloy B-2, 28\% Mo-69\% Ni) is available as a commercial alloy in this class. Process experience indicated that alloy N10665 has excellent resistance to corrosion in reducing acids such as hydrochloric and dilute sulfuric acids at moderate temperatures (ASM 1985). The AC impedance test showed that alloy N10665 had excellent corrosion resistance to $5 \mathrm{wt} \%$ sulfuric acid at 90 and $100^{\circ} \mathrm{C}$. Corrosion rates were 1 and $2 \mathrm{mpy}$, respectively. The corrosion rate increased significantly to 15 and 299 mpy when temperatures were increased to 120 and $140^{\circ} \mathrm{C}$. Similar to test results on N02200 and N04400, alloy N10665 did not passivate in the $5 \mathrm{wt} \%$ sulfuric acid solution. The anodic polarization curves exhibited a classical Tafel relationship. An increase in alloy N10665 corrosion was evidenced by shifting of the alloy polarization curves in the direction of increased current density.

\section{Ni-Cr-Mo-Fe Alloys}

The two representative alloys of this class selected for testing were alloy N08825 (Incoloy $825,22 \% \mathrm{Cr}-29 \% \mathrm{Fe}-3 \% \mathrm{Mo}-42 \% \mathrm{Ni}$ ) and alloy N06030 (Hastelloy G-30, 30\% Cr-15\% Fe-5.5\% $\mathrm{Mo}-43 \% \mathrm{Ni}$ ). With higher chromium and lower iron content, alloy N06030 is expected to corrode less severely than alloy N08825 in the 5 $w t \%$ sulfuric acid solution. At $90^{\circ} \mathrm{C}$, both materials exhibited excellent resistance to corrosion. The corrosion rate was less than 1 mpy. Examination of anodic polarization curves showed stable passivation of alloys $\mathrm{N} 06030$ and N08825 and low passive current densities, 1.5 and $2.5 \mu \mathrm{A} / \mathrm{cm}^{2}$, respectively (Fig 1). Both alloys passivated spontaneously and corroded in the passive range when tested at $90^{\circ} \mathrm{C}$ because the 
corrosion potential was more noble than the primary passivation potential, $\mathrm{E}_{\mathrm{pp}}$. The $\mathrm{E}_{\mathrm{pp}}$ was not found in the anodic polarization measurements for either alloy at $90^{\circ} \mathrm{C}$ because it was more active than the low end of the test range. The breakdown potential of both alloys was approximately $290 \mathrm{mV} / \mathrm{Pt}$. Similar results were observed when these alloys were tested at $100^{\circ} \mathrm{C}$. Both test materials showed excellent corrosion resistance with corrosion rates of less than 1 mpy. Stable passivation was also found in both test materials with low passive current densities, $3 \mu \mathrm{A} / \mathrm{cm}^{2}$ for alloy $N 08825$ and $1 \mu \mathrm{A} / \mathrm{cm}^{2}$ for alloy N06030. Both alloys had a breakdown potential of $363 \mathrm{mV} / \mathrm{Pt}$.

Corrosion increased significantly when the alloys were tested at $120^{\circ} \mathrm{C}$. Both alloys N06030 and N08825 showed fair corrosion resistance with corrosion rates of 8 to $9 \mathrm{mpy}$. Although passivation was still observed on these alloys, it was less stable and protective because the passive current density was relatively high, 9 to $10 \mu \mathrm{A} / \mathrm{cm}^{2}$ (Fig 2). The corrosion potential of alloy N08825 became more active than the $E_{p p}$. This indicated that corrosion of the alloy shifted completely to the active region. At $120^{\circ} \mathrm{C}$, corrosion of alloy N06030 still remained in the passive range because the corrosion potential was more noble than $\mathrm{E}_{\mathrm{pp}}$. However, the corrosion rate was high because alloy N06030 passivated at a high passive current density $\left(9 \mu \mathrm{A} / \mathrm{cm}^{2}\right)$. Moreover, the corrosion potential of alloy N06030 was only slightly more noble than the $\mathrm{E}_{\mathrm{pp}}$, approximately $45 \mathrm{mV}$. Thus, alloy N06030 could easily corrode in the active or activepassive region. General corrosion of both alloys N08825 and N06030 was high at $140^{\circ} \mathrm{C}$. The rates were in the hundreds of mpy. Passivation of these two alloys was unstable and unprotective. The passive range was narrow and $i_{c}$ was exceedingly high, approximately 50 $\mu \mathrm{A} / \mathrm{cm}^{2}$ for alloy $\mathrm{N} 06030$ and $100 \mu \mathrm{A} / \mathrm{cm}^{2}$ for alloy N08825.

\section{Ni-Cr-Mo Alloys}

Alloys N08625 (Inconel 625, 22\% Cr-5.0 Fe-9\% $\mathrm{Mo}-4 \% \mathrm{Nb}-62 \% \mathrm{Ni}$ ), N06022 (Hastelloy C-22, $22 \% \mathrm{Cr}-10 \% \mathrm{Mo}-2 \% \mathrm{Nb}-3 \% \mathrm{~W}-53 \% \mathrm{Ni})$, and
N10276 (Hastelloy C-276, 16\% Cr-5.5\% Fe-16\% $\mathrm{Mo}-4 \% \mathrm{~W}-57 \% \mathrm{Ni}$ ) were selected in this class of alloys. In the chemical process industry, these alloys have shown excellent corrosion resistance to various acid environments (ASM 1985). Similar to results of the $\mathrm{Ni}-\mathrm{Cr}-\mathrm{Mo}-\mathrm{Fe}$ alloys, these test materials exhibited excellent corrosion resistance at temperatures approaching $100^{\circ} \mathrm{C}$. The alloys corroded at rates less than 1 mpy. AC impedance analysis showed that corrosion resistance of these alloys shifted to fair and to unsatisfactory as test temperatures were increased to 120 and $140^{\circ} \mathrm{C}$, respectively.

Potentiodynamic polarization tests showed that the Ni-Cr-Mo-W alloys passivated in the same manner as the Ni-Cr-Mo-Fe alloys in $5 \mathrm{wt} \%$ sulfuric acid. Passivation was stable and occurred spontaneously in $5 \mathrm{wt} \%$ sulfuric acid at 90 and $100^{\circ} \mathrm{C}$ (Fig 1). The passive current densities of these alloys were low, 1.5 to 2.5 $\mu \mathrm{A} / \mathrm{cm}^{2}$. As test temperature increased, passivation of these alloys shifted toward conditions favorable for higher corrosion rates. Passivation was neither stable nor protective at $120^{\circ} \mathrm{C}$, because the values of $i_{p p}$ and ${ }_{i} c$ were high The $i_{c}$ values of these alloys were approximately 4 to 5 times higher than those observed at 90 and $100^{\circ} \mathrm{C}$. At $140^{\circ} \mathrm{C}$, the $i_{p}$ values of all three alloys were unacceptably high, $50 \mu \mathrm{A} / \mathrm{cm}^{2}$ and higher. Therefore, anodic protection would not be feasible under these conditions.

\section{Zirconium Alloys}

Tests were conducted on two zirconium alloys R60705 (Grade Zr 705) and R60702 (Grade Zr 702). Alloy R60705 contains approximately 91 $\mathrm{wt} \%$ zirconium $(\mathrm{Zr}), 4.5 \mathrm{wt} \%$ hafnium $(\mathrm{Hf})$, and $3 \mathrm{wt} \%$ manganese (Mn). Zirconium 702 is purer and contains approximately $95 \mathrm{wt} \% \mathrm{Zr}$, $4.5 \mathrm{wt} \% \mathrm{Hf}$, and no Mn. Because of its purity, R60702 normally exhibits better corrosion resistance than $\mathrm{R} 60705$ in most corrosive environments. However, R60705 is slightly less expensive than R60702. Generally, zirconium alloys are excellent corrosion-resistant materials when exposed to reducing environments, particularly hydrochloric acid and sulfuric acid solutions (ASM 1985). 
AC impedance tests revealed that both zirconium alloys showed excellent corrosion resistance to the $5 \mathrm{wt} \%$ sulfuric acid solution at temperatures up to $170^{\circ} \mathrm{C}$. The corrosion rate was less than 1 mpy. Impedance of both alloy corrosion systems was extremely high, over several thousand ohms. At $180^{\circ} \mathrm{C}$, alloy $\mathrm{R} 60702$ still showed excellent resistance to general corrosion in the $5 \mathrm{wt} \%$ sulfuric acid solution. The corrosion rate was approximately $2 \mathrm{mpy}$. Corrosion resistance of alloy R60702 was good (corrosion rate of 3 to 4 mpy) at 190 and $200^{\circ} \mathrm{C}$ and was fair at 210 and $220^{\circ} \mathrm{C}$ (corosion rate of 5 and $6 \mathrm{mpy}$ ). Corrosion of alloy R60705 increased significantly at temperatures above $170^{\circ} \mathrm{C}$. The alloy showed good corrosion resistance ( $4 \mathrm{mpy}$ ) at 180 and $190^{\circ} \mathrm{C}$, fair resistance (7 mpy) at $200^{\circ} \mathrm{C}$, and poor resistance at 210 and $220^{\circ} \mathrm{C}(13$ and $20 \mathrm{mpy}$, respectively).

Potentiodynamic polarization tests revealed that passivation of zirconium alloys was stable and spontaneous over a wide range of applied potential (Fig 1-3). The corrosion potential of both alloys was more noble than $E_{p p}$ at all test temperatures. Strong and protective passivation of the alloys was also demonstrated by the fact that $E_{p p}$ and $E_{b}$ values were completely beyond the test range and could not be determined at temperatures below $200^{\circ} \mathrm{C}$ (Fig. 3). In addition, passive current density was low at most test temperatures, less than $3 \mu \mathrm{A} / \mathrm{cm}^{2}$. At test temperatures of $200^{\circ} \mathrm{C}$ and above, $E_{p p}$ became visible on the anodic polarization curves; however, it was as high as $1400 \mathrm{mV} / \mathrm{Pt}$. Passivation of alloy R60705 became less protective at between $190^{\circ}$ to $220^{\circ} \mathrm{C}$. The passive current density was between 5 and 7 $\mu \mathrm{A} / \mathrm{cm}^{2}$ at 190 and $200^{\circ} \mathrm{C}$ and between 6 and 20 $\mu \mathrm{A} / \mathrm{cm}^{2}$ at 210 and $220^{\circ} \mathrm{C}$. Although corrosion of alloy R60705 increased significantly with test temperatures, particularly above $180^{\circ} \mathrm{C}$, the passivation of the alloy was still spontaneous. Corrosion still occurred in the passive range. No active or active-passive corrosion region was found on the anodic polarization of alloy R60705 for the temperatures tested.

Similar to alloy R60705, stable passivation occurred for alloy R60702 at all test temperatures (Fig 1-3). The passive current density was as low as $1 \mu \mathrm{A} / \mathrm{cm}^{2}$ at temperatures below $180^{\circ} \mathrm{C}$. At test temperatures $180^{\circ} \mathrm{C}$ and above, the passivation of alloy $\mathrm{R} 60702$ shifted in the direction of increasing corrosion. The passive current density increased from 2 to 3 $\mu \mathrm{A} / \mathrm{cm}^{2}$ as temperature was increased from 170 to $180^{\circ} \mathrm{C}$ and then increased to $5,8,10$, and 10 $\mu \mathrm{A} / \mathrm{cm}^{2}$ as temperature was increased to 190 , 200210 , and $220^{\circ} \mathrm{C}$, respectively. The corrosion resistance of alloy $\mathrm{R} 60702$ was better than that of alloy R60705 at all test temperatures.

\section{Tantalum and $\mathrm{Nb}-\mathrm{Ta}$ Alloys}

Tantalum and tantalum alloys are considered the best corrosion-resistant materials for exposure to both oxidizing and reducing mineral acids over wide ranges of concentration and temperature (ASM 1985). However, high costs have limited their use. Tantalum has been used only in severe conditions for which there were no suitable alternative metals. Among the commercial $\mathrm{Ta}$ alloys, $\mathrm{KBI}-40$, an alloy containing $60 \% \mathrm{Ta}$ and $40 \% \mathrm{Nb}$, is considered a superior corrosion-resistant material for many environments. AC impedance measurements showed that $\mathrm{Ta}$ has excellent corrosion resistance to $5 \mathrm{wt} \%$ sulfuric acid at temperatures up to $220^{\circ} \mathrm{C}$. The polarization resistance extrapolated from AC impedance data is many thousands ohms. Tantalum exhibited complete stability and spontaneous passivation without evidence of breakdown over a wide range of potentials. Except at 210 and $220^{\circ} \mathrm{C}$, the passive range was so large that neither primary nor breakdown potentials of tantalum were observed on the anodic polarization curves. The corrosion potential of tantalum was more noble than $E_{p p}$, so tantalum corroded in the passive range at all test temperatures. Temperature had negligible effect on the passive current density of tantalum up to $190^{\circ} \mathrm{C}$. The passive current density was 1 $\mu \mathrm{A} / \mathrm{cm}^{2}$ or less. At 200,210 , and $220^{\circ} \mathrm{C}$, i.increased slightly to approximately $3 \mu \mathrm{A} / \mathrm{cm} 2$; however, the metal remained in stable and spontaneous passivation.

AC impedance tests for $\mathrm{KBI}-40$ also showed excellent corrosion resistance in the $5 \mathrm{wt} \%$ 
sulfuric acid solution up to $200^{\circ} \mathrm{C}$ with a corrosion rate of less than $1 \mathrm{mpy}$. The corrosion rate was 3 and 2 mpy at 210 and $220^{\circ} \mathrm{C}$, respectively. Potentiodynamic polarization tests showed that passivation of $\mathrm{KBI}-40$ was spontaneous up to $200^{\circ} \mathrm{C}$. At higher test temperatures, although spontaneous passivation was still observed, the anodic polarization curves of KBI-40 shifted toward increasing the passive current density. The passive current density shifted from 2 to $5 \mu \mathrm{A} / \mathrm{cm}^{2}$ when the test temperature was increased from 190 to $200^{\circ} \mathrm{C}$. At 210 and $220^{\circ} \mathrm{C}$, the passivation of $\mathrm{KBI}-40$ was less protective, because the passive current density increased to 8 and $10 \mu \mathrm{A} / \mathrm{cm}^{2}$, respectively.

\section{Conclusions}

\section{Stainless Steels}

At 90 and $100^{\circ} \mathrm{C}$, strong evidence of stable passivation was observed on stainless steels S31603, N08904, and N08020; however, resistance to general corrosion was fair to poor when exposed to $5 \mathrm{wt} \%$ sulfuric acid. If these alloys are selected, additional corrosion protection is advised to protect these stainless steels from excessive corrosion. Alloy N08026 showed excellent corrosion resistance to $5 \mathrm{wt} \%$ sulfuric acid at temperatures to $100^{\circ} \mathrm{C}$. The alloy exhibited stable and spontaneous passivation. At $120^{\circ} \mathrm{C}$ and above, all stainless steels exhibited unstable and unprotective passivation. These alloys are unsatisfactory for service with the dilute sulfuric acid in this temperature range.

\section{Nickel, Ni-Cu and Ni-Mo Alloys}

Alloy N02200 exhibited unsatisfactory corrosion resistance due to high corrosion rates in $5 \mathrm{wt} \%$ sulfuric acid at temperatures of $90^{\circ} \mathrm{C}$ and above. Alloy N02200 did not passivate under any test conditions. Alloy N04400 exhibited excellent corrosion resistance at $90^{\circ} \mathrm{C}$ and good corrosion resistance at $100^{\circ} \mathrm{C}$. At temperatures above $100^{\circ} \mathrm{C}$, the alloy corroded severely. Alloy N10665 showed excellent corrosion resistance to
$5 \mathrm{wt} \%$ sulfuric acid at temperatures up to $100^{\circ} \mathrm{C}$. However, corrosion resistance of alloy N10665 is inadequate in $5 \mathrm{wt} \%$ sulfuric acid at temperatures of $120^{\circ} \mathrm{C}$ and above. The alloy corroded at excessive rates. Similar to the behavior of alloy N02200, no passivation was observed on alloys N04400 and N10665 in 5 $w t \%$ sulfuric acid at any test temperature.

\section{Ni-Cr-Mo-Fe and Ni-Cr-Mo-W}

These alloys showed excellent corrosion resistance in $5 \mathrm{wt} \%$ sulfuric acid at temperatures up to $100^{\circ} \mathrm{C}$. All test alloys corroded at rates of less than $2 \mathrm{mpy}$. At $120^{\circ} \mathrm{C}$, these alloys corroded at rates exceeding $5 \mathrm{mpy}$. At temperatures of $140^{\circ} \mathrm{C}$ and higher, these alloys are unsatisfactory for service with the dilute sulfuric acid. These alloys showed stable and spontaneous passivation at temperatures to $100^{\circ} \mathrm{C}$. At $120^{\circ} \mathrm{C}$ and above, the passivation was unstable and unprotective. Because of high critical and passive current densities, application of anodic protection is not recommended for these nickel-based alloys at temperatures of $120^{\circ} \mathrm{C}$ or above.

\section{Zirconium Alloys}

Zirconium alloys R60705 and R60702 showed excellent corrosion resistance in $5 \mathrm{wt} \%$ sulfuric acid up to 170 and $180^{\circ} \mathrm{C}$, respectively. Zirconium alloy $\mathrm{R} 60705$ has good corrosion resistance at temperatures of $180^{\circ}$ and $190^{\circ} \mathrm{C}$; however, the corrosion resistance of R60705 declined to fair at temperature of $200^{\circ} \mathrm{C}$ and above. Zirconium alloy R60702 showed good corrosion resistance at temperatures of 190 and $200^{\circ} \mathrm{C}$, but only fair corrosion resistance at 210 and $220^{\circ} \mathrm{C}$. R60705 showed stable and spontaneously passivation up to $170^{\circ} \mathrm{C}$. The passivation was less protective at $180^{\circ} \mathrm{C}$ and above. Alloy R60702 exhibited stable and spontaneous passivation up to $190^{\circ} \mathrm{C}$. At temperatures of $200^{\circ} \mathrm{C}$ and above, passivation was less protective.

\section{Tantalum and $\mathrm{Nb}-\mathrm{Ta}$ Alloys}

Tantalum had excellent corrosion resistance at all test temperatures. The corrosion rate of $\mathrm{Ta}$ did 
not exceed $0.1 \mathrm{mpy}$ at test temperatures up to $200^{\circ} \mathrm{C}$ and approximately $1 \mathrm{mpy}$ at 210 and $220^{\circ} \mathrm{C}$. Tantalum also passivated stably and spontaneously at all test temperatures. The $\mathrm{KBI}-40$ ( $40 \% \mathrm{Nb}-60 \% \mathrm{Ta}$ alloy) showed results similar to those obtained on tantalum. The alloy corroded at rates of 1 mpy or less at temperatures up to $200^{\circ} \mathrm{C}$. $\mathrm{KBI}-40$ showed good-to-excellent corrosion resistance at 210 and $220^{\circ} \mathrm{C}$. The alloy passivated stably and spontaneously up to $200^{\circ} \mathrm{C}$. At temperatures of 210 and $220^{\circ} \mathrm{C}$, stable passivation was still observed, but there was less protection due to passive current density's being somewhat high $\left(5-10 \mu \mathrm{A} / \mathrm{cm}^{2}\right)$.

\section{References}

ASM. 1985. Corrosion, Metals Handbook, Volume 13, 9th Edition.

ASTM. 1992. "Standard Practice for Conventions Applicable to Electrochemical Measurements in Corrosion Testing." ASTM G 3-89, Annual Book of ASTM Standards. Volume 03.02, Section 3. Philadelphia: ASTM.
Fontana, M. G., and G. W. Staehle. 1970. Advances in Corrosion Science and Technology, Volume 1, Plenum Press, New York City, New York: Plenum Press.

Liening, E. L. 1986. "Electrochemical Corrosion Testing Techniques." Process Industries Corrosion: Techniques and Practice. Houston, Texas: NACE.

Muscle Shoals Corrosion Laboratory. 1989. "Cost of Construction Materials for Chemical Plants, Mt, Files of Materials and Cost." Muscle Shoals, AL.: National Fertilizer \& Environmental Research Center, Tennessee Valley Authority.

Roetheli, R. E., J. E. Jordan, and C. E. Madewell. 1984. "Biomass Fuels Progress Report." Muscle Shoals, AL.: Tennessee Valley Authority. 
Figure 1. Potentiodynamic polarization of test metals at $90^{\circ} \mathrm{C}$

Figure 2. Potentiodynamic polarization of test metals at $120^{\circ} \mathrm{C}$

Figure 3. Potentiodynamic polarization of test metals at $140^{\circ} \mathrm{C}$

Figure 4. Potentiodynamic polarization of refractory metals at various temperatures

Figure 5. AC impedance Nyquist plots of test metals at various temperatures 

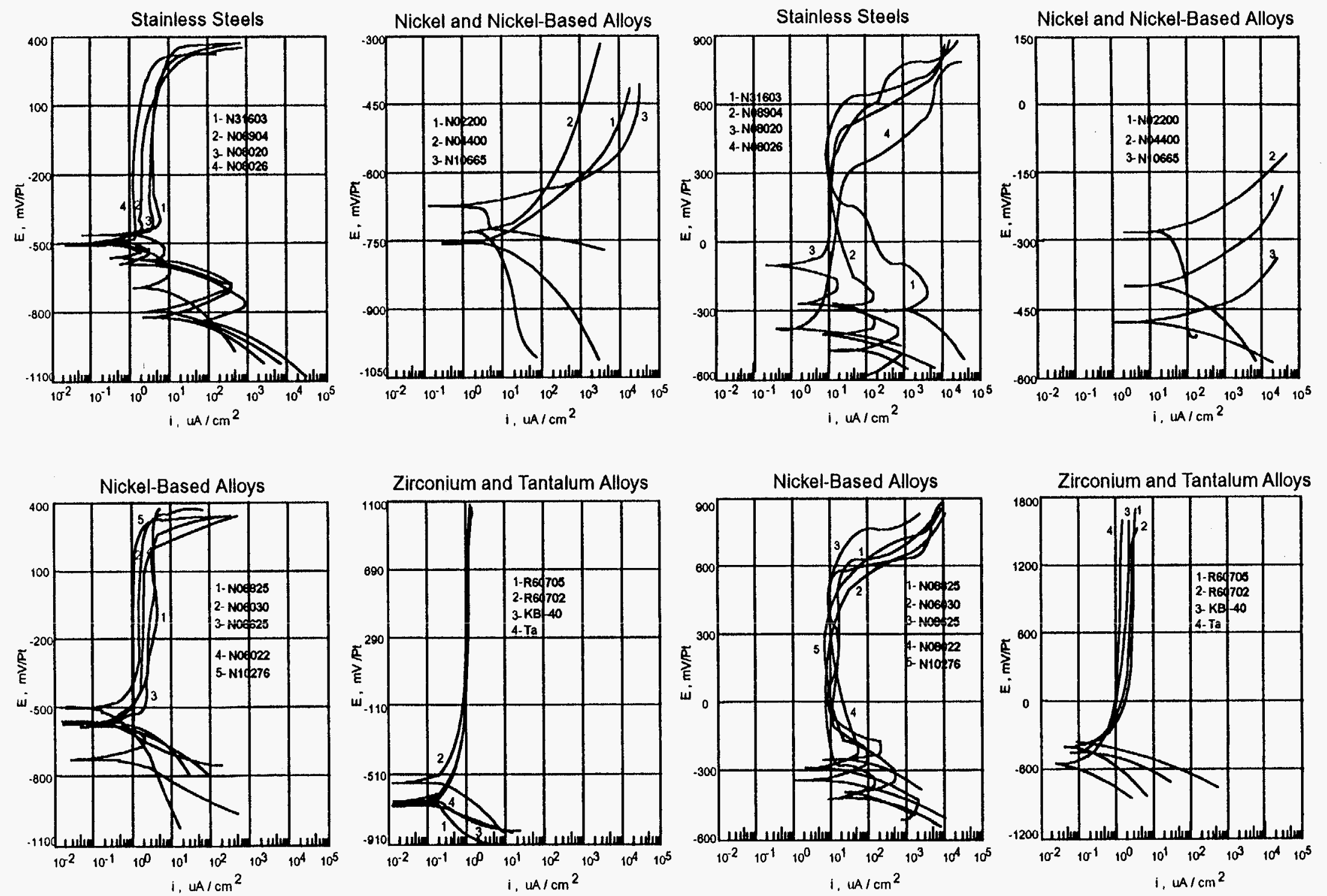

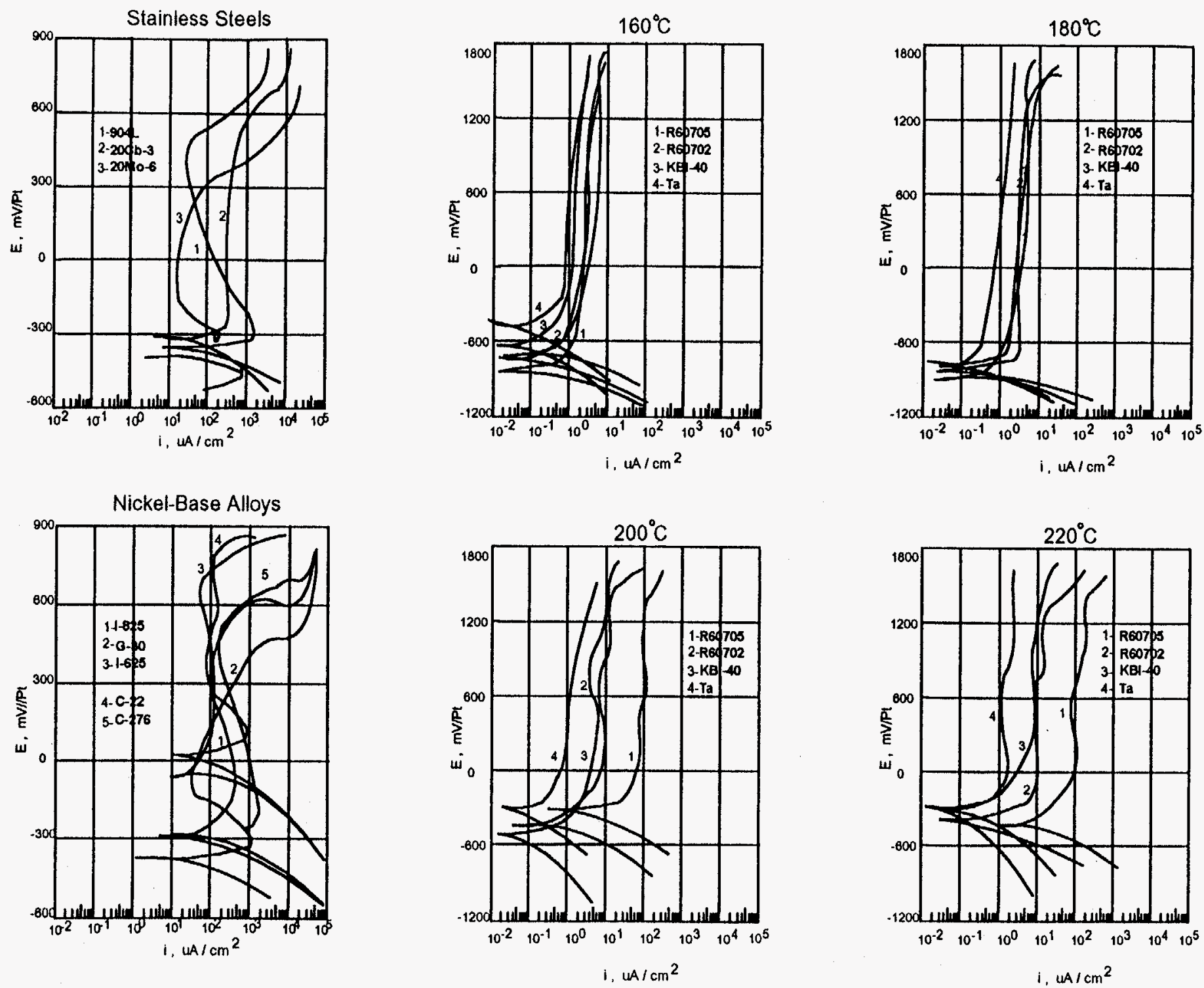


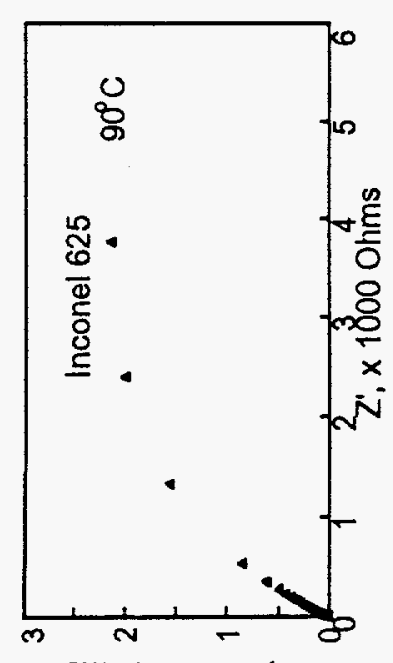

suyo $0001 \times$ ' $Z$ '
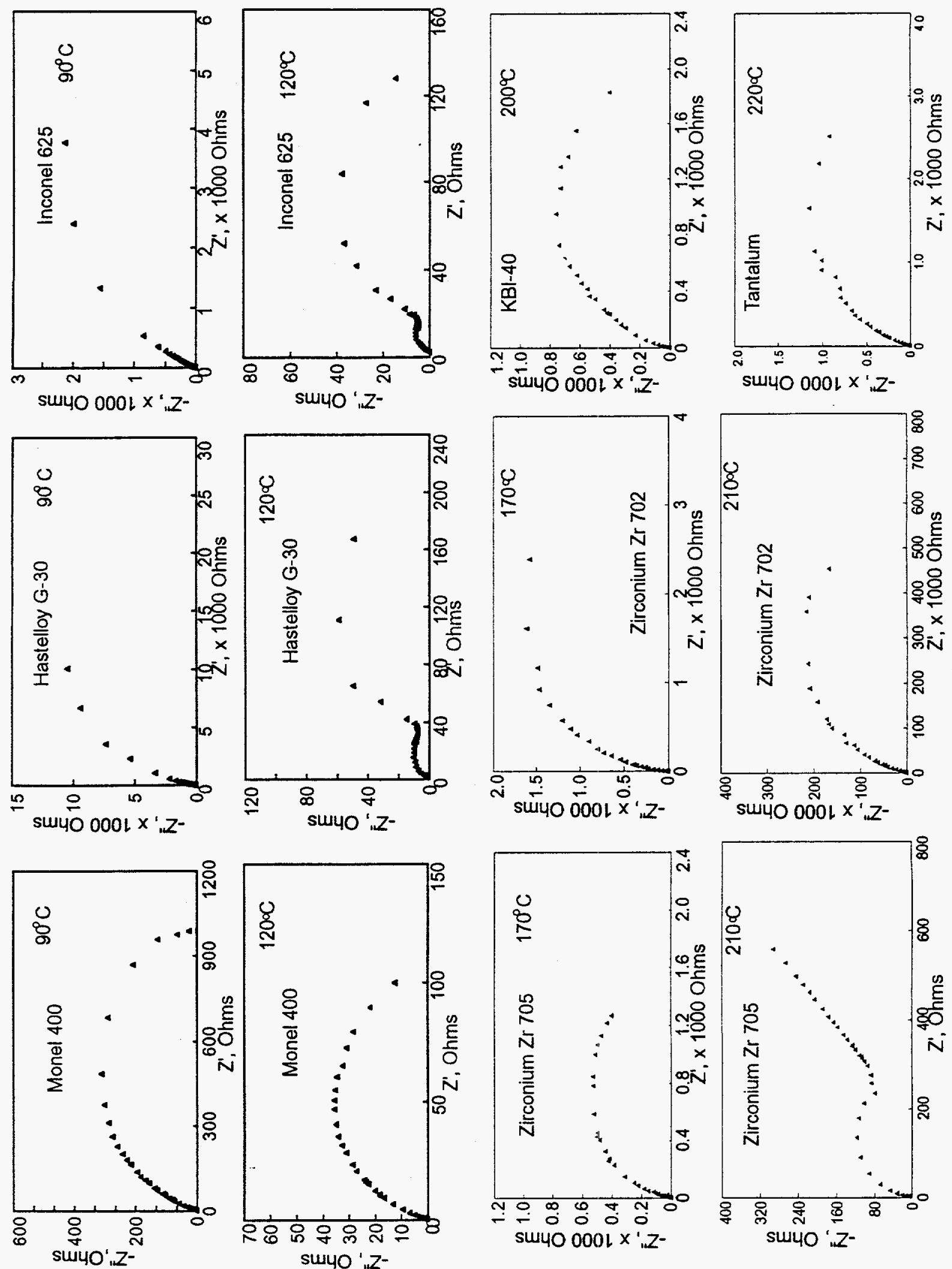

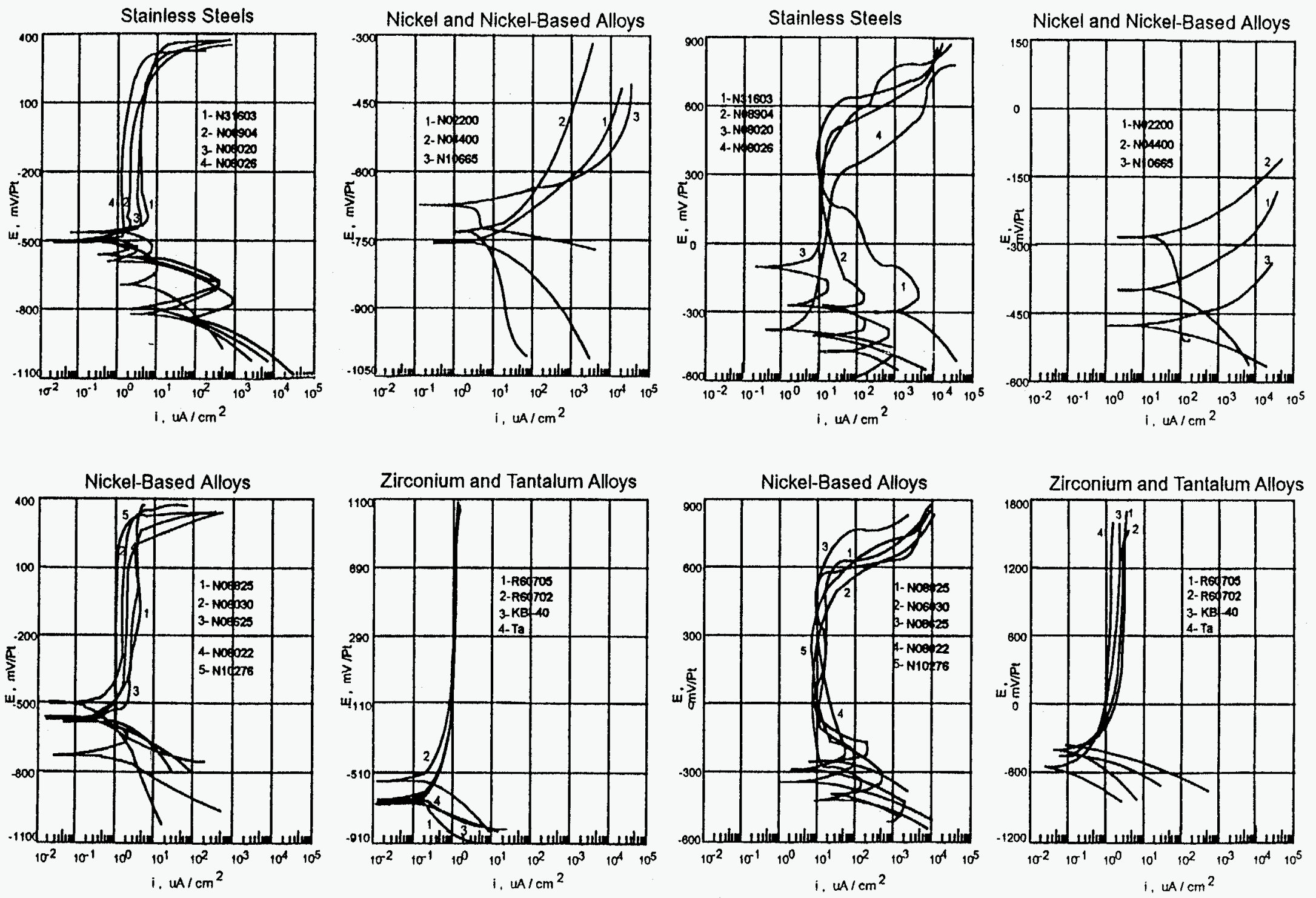

Figure 1 - Potentiodynamlc polarization of Test Materials Exposed to 5 wt\% Sulfuric Acld at $90^{\circ} \mathrm{C}$ Under Static Conditions. Test at Scan Rate of $0.17 \mathrm{mV} / \mathrm{s}$.

Flgure 2 - Potentiodynamic polarization of Test Materials Exposed to 5 wt\% Sulfuric Actå at $120 \mathrm{C}$ Under Statlc Conditions. Test at Scan Rate of $0.17 \mathrm{mV} / \mathrm{s}$. 

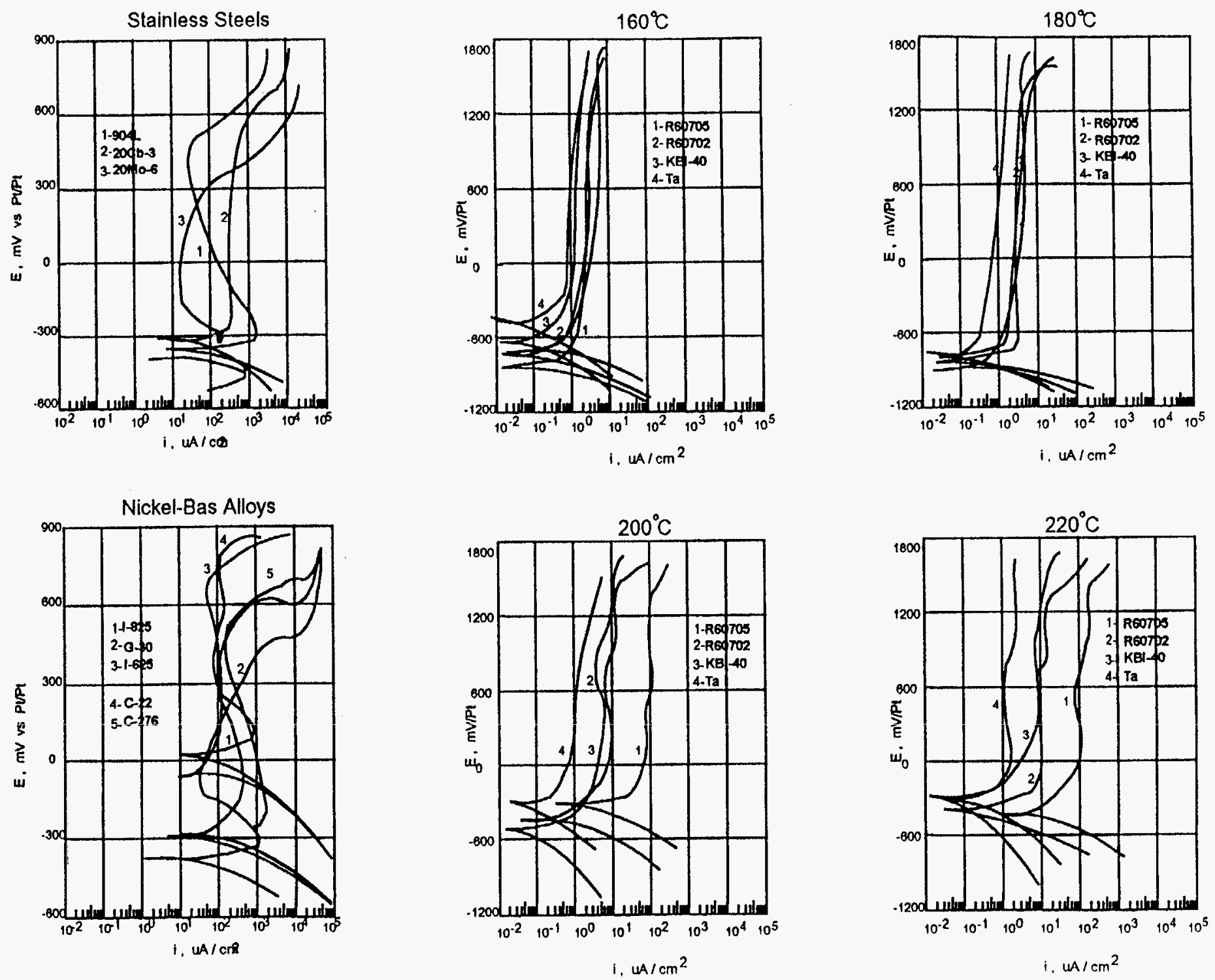

Flgure 3 - Potentiodynamic polarization of Test Materials Exposed to 5 wt\% Sulfuric Acid at $140^{\circ} \mathrm{C}$ Uhder Static Conditions. Test at Scan Rate of $0.17 \mathrm{mV} / \mathrm{s}$.

Figure 4 - Potentiodynamic polarizatlon of Refractory Metals Exposed to 5 wt\% Sulfuric Acid at at Various Temperatures Under Static Conditions. Test at Scan rate of $0.17 \mathrm{mV} / \mathrm{s}$. 

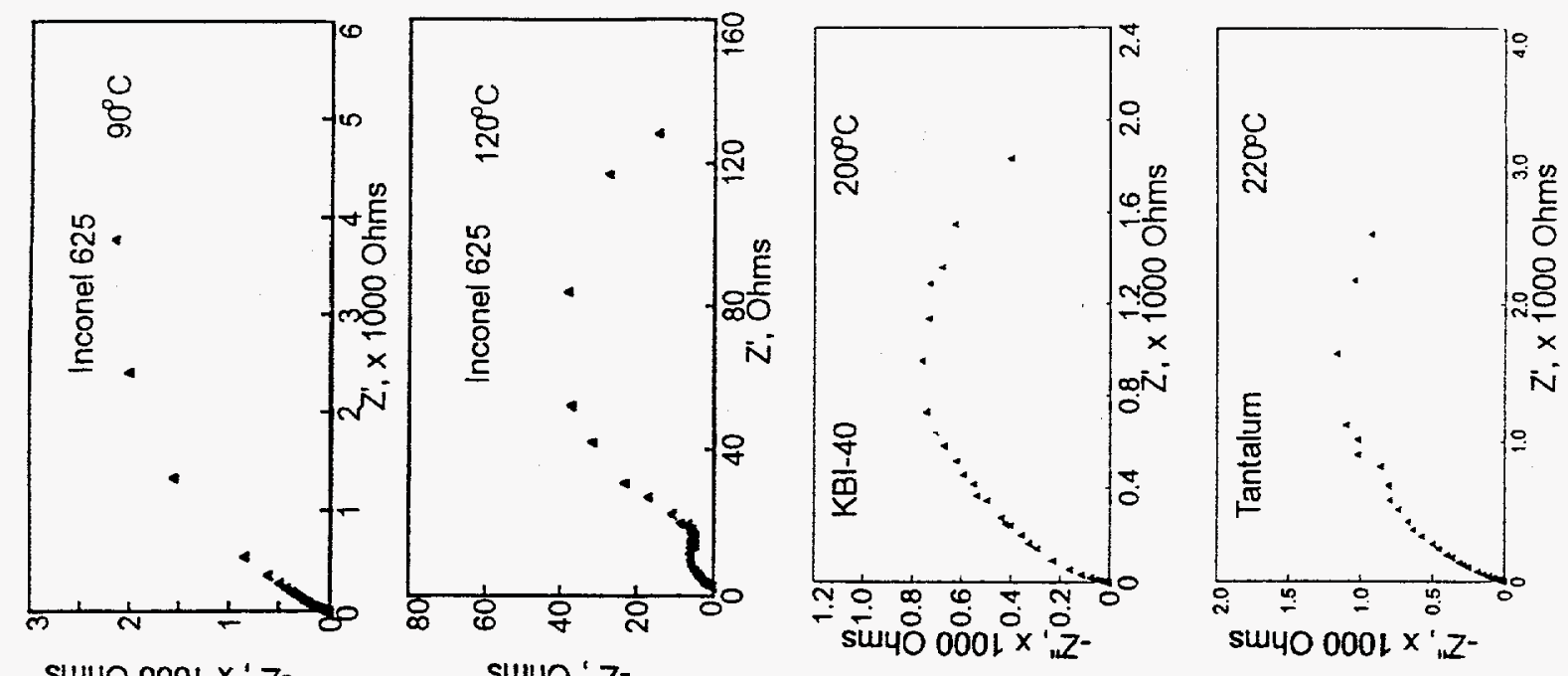

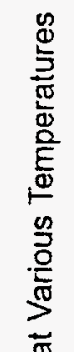
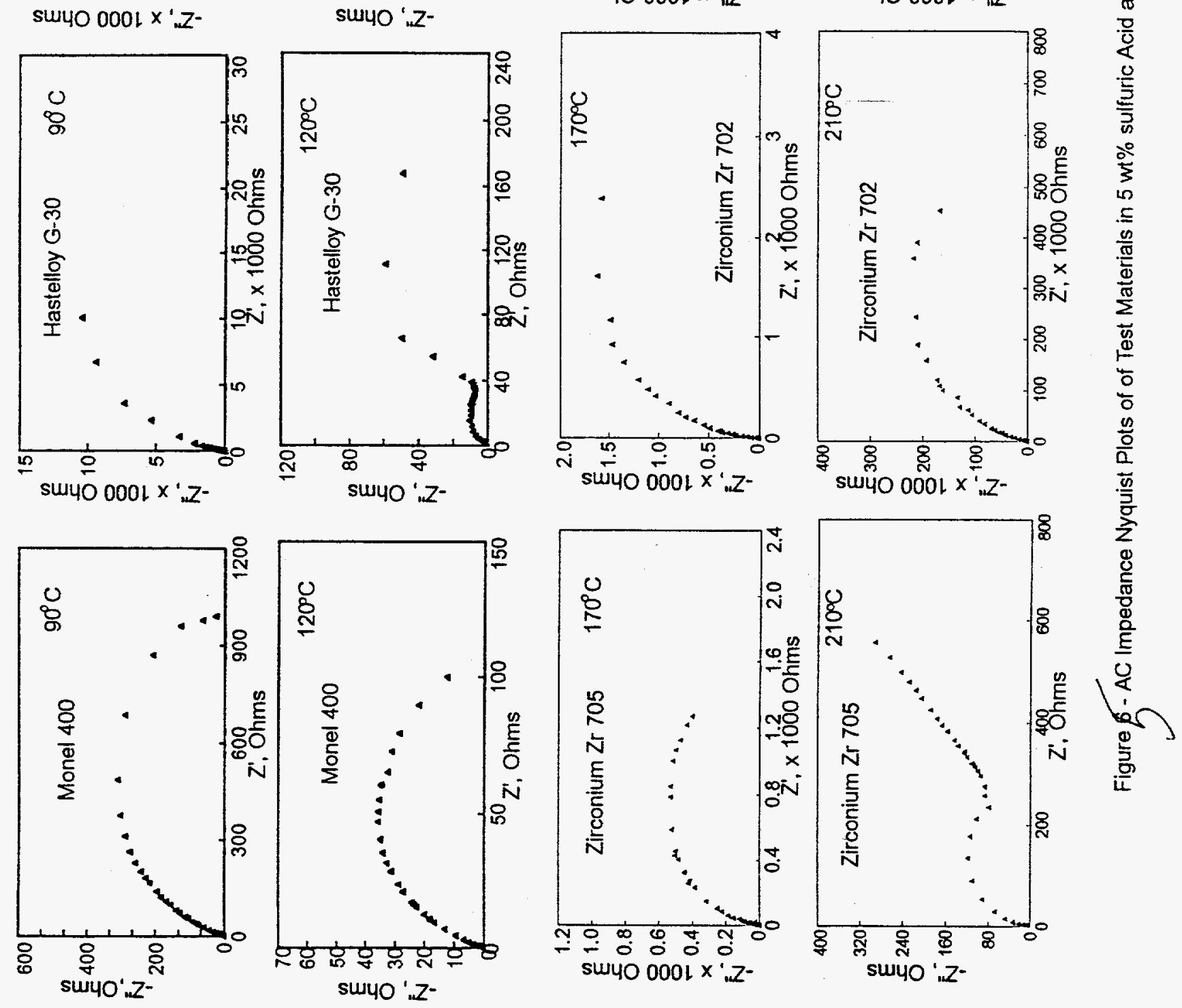